\title{
PELATIHAN SHALAT KHUSYUK MENINGKATKAN KEBAHAGIAAN PADA FAMILY CAREGIVER PASIEN STROKE
}

\author{
Futihat Nikmatul Millah \\ Qurotul Uyun \\ Rr. Indahria Sulistyarini ${ }^{1}$
}

\author{
Fakultas Psikologi dan Ilmu Sosial Budaya, Universitas Islam Indonesia
}

\section{Keywords/Kata kunci \\ devout prayer training, family caregiver, happiness, patients with stroke}

family caregiver, kebahagiaan, pasien stroke, pelatihan shalat khusyuk

\begin{abstract}
ABSTRAK:
This research aims to observe the effectiveness of the devout prayer training to improve the happiness of the family caregiver of the patients with stroke. Eight caregivers of patients with stroke were involved in this research. The subject was divided into two groups: experimental group ( $n$ $=4)$ and control group $(n=4)$. The research design used was pretest-post test control group design measured by three times (pretest, post test, and follow-up within two weeks). The measurement tools used in this research was the scale of happiness by Seligman. The result of the research showed a significant improvement in the happiness score in the family caregiver of the patients with stroke after given the treatment in the form of the devout prayer training.
\end{abstract}

\begin{abstract}
Penelitian ini bertujuan untuk mengetahui efektivitas dari pelatihan shalat khusyuk untuk meningkatkan kebahagiaan pada family caregiver pasien stroke. Delapan orang caregiver pasien stroke terlibat dalam penelitian ini. Subjek terbagi menjadi dua kelompok yaitu kelompok eksperimen $(n=4)$ dan kelompok kontrol $(n=4)$. Rancangan penelitian yang digunakan adalah prates paskates control group design dan diukur sebanyak tiga kali (prates, paskates, dan tindak lanjut selama dua minggu). Alat ukur yang digunakan dalam penelitian adalah skala kebahagiaan oleh Seligman. Hasil dari penelitian ini menunjukkan bahwa terdapat peningkatan skor kebahagiaan yang signifikan pada family caregiver pasien stroke setelah diberikan perlakuan berupa pelatihan shalat khusyuk.
\end{abstract}

\footnotetext{
${ }^{1}$ Korespondensi mengenai isi artikel dapat dilakukan melalui: 033200101@uii.ac.id
} 
Penyakit stroke merupakan salah satu penyakit kronis tidak menular yang terus meningkat jumlah pasiennya dari tahun ke tahun. Prevalensi stroke di Indonesia telah meningkat dari tahun 2013 sampai 2018, yaitu 7 per 1000 menjadi 14,7 per 1000 penduduk (Departemen Kesehatan, 2018). Selain itu, data yang diperoleh dari RSU Pusat Haji Adam Malik Medan pada tahun 2013 jumlah penderita stroke berjumlah 345 orang, kemudian pada tahun 2014 terjadi peningkatan menjadi 349 orang dan pada tahun 2015 berjumlah 278 orang (Hanum et al., 2018). Menurut Departemen Kesehatan (2018), stroke merupakan sindrom yang menempati urutan nomer satu dari penyakit tidak menular di Indonesia yang menyebabkan kematian dan kecacatan. Stroke merupakan suatu keadaan di mana terdapat gangguan aliran darah ke otak, baik berupa penyumbatan maupun pendarahan. Penyakit stroke sering dianggap sebagai penyakit yang menjangkiti para orang tua, namun sekarang ini terdapat kecenderungan juga bahwa penyakit stroke ini diderita oleh pasien di bawah 40 tahun (World Health Organization [WHO], 2014).

Pasien stroke pada dasarnya masih memiliki potensi untuk pulih setelah melewati serangan stroke. Namun, pasien yang mampu bertahan hidup pasca serangan stroke memiliki tantangan dalam menjalani kehidupannya. Pasien stroke kemungkinan akan mengalami kelumpuhan separuh badan, sulit untuk berbicara dengan orang lain (aphasia), mulut mencong (facial drop), lengan dan kaki yang lemah, gangguan koordinasi tubuh, perubahan mental, gangguan emosional, gangguan komunikasi, serta kehilangan indera rasa (Okta \& Santi, 2015). Gejala sisa ini dapat berpengaruh pada aspek fisik, psikologis serta sosial bagi pasiennya yang juga akan berdampak pada penurunan produktivitas dan kualitas hidup baik secara permanen maupun sementara.
Lebih lanjut, dampak secara fisik juga dapat muncul seperti kelumpuhan parsial, gangguan komunikasi dan gangguan kognitif. Defisit yang paling umum yang dialami pasien stroke yaitu melibatkan aksi motorik. Kelumpuhan fisik ini dapat terjadi secara langsung dan biasanya pasien menyadari bahwa ia tidak dapat menggerakkan tangan dan kaki pada satu sisi tubuh. Dampak secara psikologis seperti adanya kemarahan, merasa terisolasi, emosi yang tidak stabil, depresi, dan lain-lain (Ayuningputri \& Maulana, 2014), sedangkan dampak secara sosial yaitu membuat pasien stroke tidak dapat bekerja kembali seperti sediakala dan sosialisasi dengan lingkungan juga dapat terhambat (Yayasan Stroke Indonesia [YASTROKI], 2012).

Penyakit stroke memiliki dampak dalam jangka pendek dan juga dalam jangka panjang. Selain itu, penyakit stroke berdampak ganda, baik bagi pasien maupun caregiver. Pada umumnya pasien stroke di dalam hidupnya akan membutuhkan perawatan kesehatan yang berkelanjutan, di mana hal ini akan melibatkan caregiver dari orang-orang terdekat pasiennya baik itu pasangan, anak ataupun keluarga. Anggota keluarga pasien stroke yang bertanggungjawab untuk merawat dan mendampingi pasien selama sakit disebut dengan family caregiver. Pasien stroke sangat bergantung pada family caregivernya. Setelah awal masa rawat inap dan rehabilitasi stroke, 80\% dari pasien stroke yang bertahan hidup dengan kembali ke komunitas, bergantung pada emosi dari anggota keluarga, informasi dan bantuan peralatan untuk hidup sehari-hari. National Alliance for Caregiving (2015) menyatakan bahwa caregiver bertanggung jawab untuk memberikan dukungan fisik, emosional, dan seringkali keuangan dari orang lain yang tidak mampu untuk merawat dirinya sendiri karena sakit, cedera, atau cacat. 
Penelitian yang dilakukan oleh Cameron et al., (2014) menunjukkan bahwa sebanyak $50 \%$ dari pasien stroke mengalami kecacatan fisik yang mengakibatkan pasien mengalami kesulitan melakukan aktivitas, termasuk mandi, jalan kaki, naik tangga, melakukan pekerjaan rumah tangga, menyiapkan makanan dan bepergian. Pasien stroke tidak dapat mandiri dan memerlukan bantuan dalam pemenuhan kebutuhan sehari-hari. Kecacatan akibat stroke tidak hanya berdampak bagi penyandangnya, akan tetapi juga berdampak bagi anggota keluarga karena pasien stroke bergantung pada dukungan emosional dan fisik dari informal caregiver yang biasanya adalah anggota keluarga.

Beberapa hasil penelitian sebelumnya menunjukkan bahwa para caregiver dituntut untuk mampu mengatasi tekanan psikologis yang didapatkan dari kondisi pasien yang dirawat. Selain itu, caregiver juga diharapkan mampu memberikan dukungan secara emosional kepada pasien, selalu mendampingi pasien dan bersiap diri secara konsisten untuk pasien yang dirawat. Penelitian sebelumnya yang dilakukan oleh Daulay et al., (2014) menjelaskan bahwa caregiver seringkali mengalami stres yang disebabkan oleh beratnya tugas yang harus dilakukan dalam merawat pasien stroke. Selain itu, penelitian yang dilakukan oleh Fajriyati \& Asyanti (2017) juga menunjukkan bahwa para caregiver mengalami stres berupa kelelahan fisik, kelelahan psikis, adanya tuntutan dari keluarga serta masalah finansial. Hal tersebut sesuai dengan hasil wawancara terhadap caregiver pasien stroke yang menunjukkan bahwa caregiver mengalami masalah pada berbagai aspek antara lain aspek fisik, emosi, finansial dan juga sosial.

Berdasarkan hasil wawancara yang dilakukan kepada salah satu caregiver pasien stroke yang berinisial $\mathrm{N}$, bahwa semenjak merawat orang tuanya yang menderita stroke, dirinya merasa waktunya habis hanya untuk merawat orangtuanya di rumah sepanjang hari, sehingga tidak ada waktu untuk sekedar bersosialisasi dengan lingkungan sosial. $\mathrm{N}$ juga merasa dirinya menjadi mudah merasa lelah dan menjadi mudah terserang penyakit. Munculnya perasaan sedih dan kesal kepada pasien yang membuat $\mathrm{N}$ menjadi terkadang tidak bersemangat dalam merawat orangtuanya. Berdasarkan pernyataan tersebut menunjukkan bahwa $\mathrm{N}$ mengalami penurunan tingkat kebahagiaan (Wawancara, 25/3/2017).

Hasil wawancara yang telah dilakukan sesuai dengan pernyataan Fahrunnisa \& Solichach (2017) bahwa caregiver yang merawat keluarganya berpengaruh pada aspek emosional, fisik dan sosial. Pada aspek emosional (psikologis) respon yang sering muncul adalah depresi, marah, kecewa dan ketakutan. Dampak yang terlihat pada aspek fisik adalah kelelahan, sakit otot, insomnia, hipertensi bahkan penyakit jantung. Sedangkan pada aspek sosial berdampak pada terbatasnya sosialisasi dengan lingkungan sekitar, hilangnya privacy, terbatasnya interaksi dengan anggota kelurga yang lain serta terganggunya pola tidur caregiver.

Menurut National Alliance for Caregiving (2015) ada dua jenis caregiver, yaitu caregiver formal dan caregiver informal. Pada kasus stroke, caregiver harus menemani pasien selama hampir 24 jam untuk memenuhi segala kebutuhan pasien. Kebutuhan pasien stroke bervariasi dari fisik, komunikasi (verbal dan nonverbal), keperawatan, serta perubahan emosional dan psikologis. Hal tersebut membuat caregiver harus menyeimbangkan tanggung jawab ganda untuk merawat pasien stroke. Caregiver harus membagi waktu antara pekerjaan, keluarga dan merawat pasien stroke, sehingga memunculkan perasaan cemas, menurunnya kebahagiaan, hingga depresi (Agusthia, 2018). 
Kebahagiaan merupakan konsep subjektif di mana setiap individu memiliki tolak ukur yang berbeda tentang kebahagiaan. Kebahagiaan individu dapat dilihat dari emosi positif. Emosi positif terdiri atas kepuasan akan masa lalu, optimis akan masa depan, dan bahagia di masa kini (Seligman, 2005). Ketiga emosi positif tersebut menjadi keinginan bagi setiap individu untuk merasakannya, namun terkadang hal tersebut tidak dapat tercapai. Sebagai contoh, mungkin saja individu merasa puas pada masa lalunya, namun merasa sedih pada masa sekarang, dan menjadi pesimis tentang masa depannya. Ketika individu dapat mengetahui dan mempelajari ketiga bentuk emosi positif, diharapkan individu dapat mengarahkan emosinya ke arah yang positif. Misal dengan mengubah perasaan negatif menjadi positif tentang masa lalu, cara berpikir tentang masa depannya, dan cara menjalani kehidupannya pada saat ini.

Kebahagiaan juga mewakili suatu bentuk interaksi antara manusia dengan lingkungannya. Manusia dapat bahagia dari diri sendiri dan bahagia untuk dirinya sendiri. Di sisi lain, manusia juga dapat bahagia karena orang lain dan untuk orang lain. Hal tersebut menunjukkan bahwa kebahagiaan tidak bersifat egoistis melainkan dapat dibagi kepada orang lain dan lingkungan sekitar (Rahardjo, 2007). Ketika seorang caregiver dalam merawat pasien stroke dalam keadaan bahagia, maka dapat memberikan kebahagiaan juga bagi pasien stroke.

Berbeda halnya ketika seorang caregiver memiliki kebahagiaan yang rendah, tentu akan mempengaruhi kondisi pasiennya. Perubahan dalam diri caregiver dalam merawat salah satu anggota keluarga yang menderita stroke menunjukkan adanya dampak negatif dalam diri caregiver, salah satunya adalah dalam segi emosional seperti perasaan mudah marah, ketakutan, kesal atau kecewa, dan depresi. Apabila caregiver tidak mampu mengontrol emosinya, maka akan berdampak juga bagi kondisi psikologis pasiennya yang dapat merasa bersalah dan tertekan. Padahal, kondisi psikologis pasien penyakit kronis akan mempengaruhi keparahan dari penyakitnya (Icekson et al., 2014).

Kebahagiaan sangat penting bagi caregiver dalam merawat pasien stroke yang dapat berdampak bagi kondisi kesehatan pasiennya. Oleh karena itu, diperlukan suatu cara yang dapat meningkatkan kebahagiaan. Pada penelitian ini, peneliti memiliki tujuan untuk menawarkan intervensi dalam meningkatkan kebahagiaan caregiver pasien stroke dengan bentuk intervensi religiusitas Islam. Salah satu faktor yang mempengaruhi kebahagiaan adalah religiusitas (Seligman, 2005). Beberapa individu yang memiliki keyakinan yang kuat kepada Tuhan akan terus berjuang dan memiliki motivasi yang tinggi, dengan keyakinan tersebut dapat melepaskan beban berat yang di rasakannya sehingga akan menimbulkan emosi positif dan kebahagiaan. Hal tersebut sesuai dengan penelitian sebelumnya yang dilakukan oleh Ros Mayasari (2014) bahwa religiusitas berkontribusi secara langsung ataupun tidak langsung terhadap kebahagiaan individu melalui pemberian makna dan tujuan hidup manusia. Religiusitas tampak lebih dekat dengan konsep kesejahteraan psikologis yang menekankan kebahagiaan terhadap adanya hidup yang bermakna.

Adapun beberapa penelitian yang menjelaskan mengenai penanganan religiusitas yaitu penelitian yang dilakukan oleh Ifadah (2015) yang menjelaskan mengenai pelatihan kekuatan diri berbasis syukur untuk meningkatkan kebahagiaan pada wanita muslim yang berperan ganda. Intervensi yang dilakukan dalam penelitian tersebut mampu meningkatkan kebahagiaan pada wanita muslim yang berperan ganda. Intervensi tersebut dapat efektif apabila diaplikasikan dalam kegiatan sehari-hari. Peningkatan kebahagiaan dapat dipengaruhi 
oleh intervensi yang telah dilakukan oleh terapis sebelumnya, namun tidak dipraktekkan oleh subjek penelitian setiap hari ketika merasa sedih atau tingkat kebahagiaannya menurun. Apabila subjek penelitian mempraktekkan setiap hari kemungkinan akan terus meningkat kebahagiaannya.

Penelitian lainnya yang juga menjelaskan mengenai hubungan antara religiusitas dan kebahagiaan adalah penelitian yang dilakukan oleh Pontoh \& Farid (2015) yang menunjukkan bahwa religiusitas memiliki hubungan yang signifikan terhadap kebahagiaan individu. Individu yang memiliki kepercayaan terhadap agama yang kuat, memiliki kepuasan hidup yang lebih tinggi, kebahagiaan personal yang lebih tinggi, serta mengalami dampak negatif peristiwa traumatis yang lebih rendah jika dibandingkan individu yang tidak memiliki kepercayaan terhadap agama yang kuat. Hal tersebut menunjukkan bahwa kebahagiaan caregiver pasien stroke dapat ditingkatkan dengan religiusitas.

Beberapa penelitian sebelumnya belum banyak yang menggunakan intervensi religius kepada caregiver pasien stroke, seperti penelitian yang dilakukan oleh Agusthia (2018) mengenai pengaruh terapi psikoedukasi terhadap beban caregiver dalam merawat pasien stroke. Terapi psikoedukasi berupa pemahaman mengenai penyakit stroke dan juga manajemen stres kepada caregiver dikatakan efektif untuk menurunkan beban yang dirasakan caregiver yang merawat pasien stroke. Terapi tersebut juga kurang memberikan solusi bagi caregiver pasien stroke di kemudian hari, mengingat bahwa terapi yang diberikan hanya berdampak pada saat diberikan dan kemungkinan tidak akan dipertahankan oleh caregiver pasien stroke di kemudian hari. Caregiver pasien stroke membutuhkan intervensi religiusitas yang dapat terus diingat dan dipraktekkan dalam kehidupan sehari-hari karena ibadah merupakan kebiasaan atau aktivitas seharihari yang dilakukan setiap muslim, sehingga caregiver pasien stroke dapat terus mempraktekkan intervensi religius yang telah diberikan.

Selain itu, penelitian yang dilakukan oleh Sari \& Subandi (2015) yaitu menggunakan pelatihan teknik relaksasi untuk menurunkan kecemasan pada caregiver pasien kanker payudara. Intervensi berupa teknik relaksasi dapat memberikan ketenangan namun hanya sesaat, dikarenakan perlunya intervensi tambahan yang dapat memperkuat menurunnya kecemasan yang dialami oleh caregiver pasien kanker payudara. Teknik relaksasi dirasa kurang memberikan solusi untuk mempertahankan ketenangan yang dialami oleh individu, sehingga diperlukan adanya intervensi religius untuk memberikan ketenangan jiwa dalam menghadapi kehidupan. Masih kurangnya penelitian mengenai pemberian intervensi religius pada caregiver penyakit kronis. Hal tersebut membuat peneliti tertarik untuk melakukan penelitian dengan memberikan intervensi religius kepada caregiver penyakit kronis yang dapat dilakukan setiap hari, misalnya subjek melakukan ibadah shalat secara khusyuk yang dapat memberikan kebahagiaan. Intervensi religius tersebut dapat dilakukan subjek penelitian pada lima waktu dalam sehari, sehingga intervensi religius yang diberikan bermanfaat jika diaplikasikan oleh subjek penelitian setiap hari.

Adapun penelitian sebelumnya yang dilakukan oleh Wardani et al., (2016) yaitu menggunakan pelatihan shalat khusyuk yang dilakukan untuk menurunkan kecemasan pada lansia hipertensi. Hasil dari penelitian tersebut adalah adanya pengaruh pelatihan shalat khusyuk untuk menurunkan kecemasan pada lansia hipertensi. Selain itu, penelitian lainnya yang dilakukan oleh Nurtalatthaf (2017) yang 
menggunakan pelatihan shalat khusyuk untuk meningkatkan kebermaknaan hidup pada penyandang disabilitas fisik. Penelitian tersebut juga menunjukkan adanya pengaruh pelatihan shalat khusyuk terhadap peningkatan kebermaknaan hidup pada penyandang disabilitas fisik. Berdasarkan penelitian-penelitian sebelumnya, dapat dilihat bahwa adanya pengaruh positif setelah diberikan salah satu bentuk intervensi religius yaitu pelatihan shalat khusyuk pada individu yang memiliki permasalahan di dalam hidupnya.

Salah satu bentuk dari aspek religiusitas adalah shalat, di mana dalam shalat terdapat kekhusyukan. Shalat merupakan kewajiban setiap muslim dan menjadi tiang agama. Ketika seorang muslim melaksanakan shalat, secara tidak langsung pikiran dan perasaannya akan ikut merasakan. Bahwa shalat itu akan membuat perasaan menjadi lebih tenang dan bahagia. Secara fitrah, manusia menginginkan ketenangan, kedamaian, dan kebahagiaan dalam hidupnya. Umat Islam memiliki cara untuk meraih kebahagiaan, yaitu dengan shalat secara khusyuk. Di dalam shalat yang khusyuk terdapat gerakan dan bacaan tertentu sebagai terapi mental spiritual dan kesehatan tubuh, sehingga diharapkan memberi manfaat bagi yang melaksanakannya. Shalat merupakan cara yang paling mudah untuk mendapatkan ketenangan, kebahagiaan, dan kedamaian. Tanpa disadari, shalat dapat dijadikan penolong, penerang jiwa, tempat mengadu ketika persoalan duniawi terlihat sulit dihadapi (Sangkan, 2004).

Shalat menjadi salah satu ibadah yang merupakan dialog langsung antara hamba dengan Allah SWT. Dialog tersebut menunjukkan bahwa hamba menyatakan ke Maha Esa-an dan kebesaran Allah SWT, penyerahan diri secara total, permohonan perlindungan dan kebebasan dari segala mara bahaya dan serta memohon kebahagiaan dunia dan akhirat. Shalat dapat memberikan dampak bagi kondisi psikologis menjadi lebih tenang. Hal tersebut sesuai dengan pernyataan Suparman, (2015) bahwa shalat 5 waktu adalah asupan bernutrisi bagi ruh, jika seorang hamba bermunajat kepada Tuhannya melalui shalat, hatinya akan semakin terang, dan dadanya pun semakin lapang. Di dalam shalat akan lebih baik dan memberikan manfaat jika menghadirkan kekhusyukan.

Khusyuk di dalam shalat merupakan kondisi hati yang penuh dengan rasa takut, pasrah, tunjuk dan sejenisnya yang tampak dalam setiap gerakan shalat sehingga menunjukkan khidmat dan juga fokus terhadap shalatnya. Sedangkan khusyuk menurut Sangkan (2004) merupakan buah dari iman kepada-Nya dan shalat yang benar bukan sekedar memahami makna shalat, tetapi juga menghadirkan hati untuk merasakan dan menikmati gerakan shalat dari takbir hingga salam dalam tatapan Allah, perhatian Allah, dan pendengaran Allah. Oleh karena itu, dengan shalat khusyuk kondisi psikologis caregiver menjadi semakin baik, terutama kebahagiaan dan ketenangan yang semakin meningkat setelah menerapkan shalat khusyuk di dalam kehidupannya ketika merawat pasien stroke. Apabila caregivernya bahagia, maka pasiennya juga akan merasakan hal positif yang ditularkan oleh caregiver-nya.

Berdasarkan latar belakang masalah yang telah dijelaskan di atas, peneliti melakukan penelitian untuk mengetahui pengaruh pelatihan shalat khusyuk terhadap peningkatan kebahagiaan pada caregiver pasien stroke.

\section{METODE PENELITIAN}

\section{Desain Penelitian}

Desain penelitian yang digunakan pada penelitian ini adalah disain penelitian kuasi eksperimen. Desain kuasi eksperimen berarti eksperimen yang dilakukan seolah- 
olah menyerupai keadaan yang sebenarnya. Jenis desain yang digunakan dalam penelitian ini, yaitu the non-randomized control group prates-paskates design yang berarti desain penelitian ini melakukan pembentukan kelompok yang diambil secara acak serta akan mengadakan pra-uji dan pasca-uji.

\section{Subjek Penelitian}

Subjek pada penelitian ini adalah caregiver anggota keluarga yang menderita stroke dan tercatat sebagai pasien di Puskesmas Mlati 2, Sleman, Yogyakarta. Subjek dalam penelitian ini berjumlah 8 orang yang memiliki kriteria yaitu memiliki anggota keluarga yang menderita stroke, memiliki tingkat kebahagiaan yang sedang atau rendah berdasarkan skala kebahagiaan, berjenis kelamin laki-laki ataupun perempuan, mampu membaca dan menulis, pendidikan terakhir minimal SMP, beragama Islam dan melaksanakan shalat 5 waktu setiap hari.

\section{Metode Pengumpulan Data}

Variabel kebahagiaan diukur menggunakan skala kebahagiaan yang disusun berdasarkan aspek-aspek kebahagiaan yang telah dikemukakan oleh Seligman (2005). Aspek-aspek tersebut yaitu emosi positif di masa lalu, emosi positif di masa sekarang, dan emosi positif di masa depan.

\section{Prosedur Intervensi}

1. Persiapan Penelitian

Persiapan yang dilakukan peneliti dalam penelitian ini adalah persiapan-persiapan yang berkaitan dengan administrasi, persiapan alat ukur, dan persiapan modul pelatihan. Rincian masing-masing persiapan yang dilakukan adalah: a. Persiapan Administrasi

Peneliti mengawali penelitian dengan melakukan persiapanpersiapan yang berkaitan dengan administrasi penelitian dan perizinan penelitian.

b. Persiapan Alat Ukur Penelitian

Alat ukur yang digunakan dalam penelitian ini adalah skala kebahagiaan (the authentic happiness inventory) yang disusun oleh Seligman (2005) Skala kebahagiaan ini mengukur kebahagiaan secara umum dan memuat aspek emosi positif di masa lalu, emosi positif di masa sekarang, dan emosi positif di masa depan. Skala kebahagiaan ini berjumlah 24 butir pertanyaan, yang terdiri dari 12 butir positif (favorable) dan 12 butir negatif (unfavorable). Skala tersebut terdiri atas empat alternatif jawaban yaitu Sangat Sesuai, Sesuai, Tidak Sesuai, dan Sangat Tidak Sesuai.

c. Persiapan Modul

Modul pelatihan shalat khusyuk ini diperoleh dari modul pelatihan shalat khusyuk yang dikembangkan oleh Wardani et al., (2016). Kemudian peneliti memodifikasi dengan melakukan penyusunan modul yang disesuaikan oleh kebutuhan subjek penelitian yaitu untuk meningkatkan kebahagiaan subjek yang sebelumnya merasa terbebani, sedih dan stres karena harus merawat pasien stroke selama 24 jam. Selain itu, peneliti juga mengganti landasan teori yang digunakan dalam modul penelitian sebelumnya, dengan teori dari kitab AlGhazali mengenai Ihya' ulumuddin yang di dalamnya menjelaskan juga mengenai ibadah shalat. Menurut AlGhazali (2011) shalat khusyuk memerlukan usaha dalam upaya menenangkan diri dengan cara memberikan perintah kepada pikiran, perasaan anggota tubuh agar tenang. Adapun enam hal yang perlu 
diperhatikan dalam shalat khusyuk antara lain:

(1) Hudhuru al-qalb yaitu kosongnya jiwa selain apa yang dikerjakan dan diucapkan, sehingga perbuatan maupun ucapan selalu sama dengan apa yang ada di dalam qalbu.

(2) Al-Tafahhum yaitu memahami makna kalimat atau ucapan yang disampaikan dengan melibatkan fungsi akal untuk memahami kandungan makna yang menyertainya.

(3) Al-Ta'zhim atau pengagungan dan penghormatan kepada Allah Swt, merupakan syarat bagi hadirnya qalbu dalam pelaksanaan shalat.

(4) Al-Haibah atau sikap takut kepada Allah Swt, yang merupakan kondisi qalbu sebagai akibat dari pengetahuan tentang kekuasaan Allah

(5) Al-Raja' atau pengharapan, yang muncul karena keimanan yang sangat kuat dalam perkara-perkara seperti pengetahuan akan kasih sayang dan karunia Allah Swt

(6) Al-Haya' atau rasa malu, yang muncul akibat kesadaran atau ketidakkuasaan hamba dalam beribadah kepada Allah Swt

Peneliti juga membutuhkan penilaian profesional oleh ahlinya yang berkaitan dengan modul intervensi. Penilaian profesional ini telah dilakukan oleh ahli yang mempelajari dan mempraktekkan pelatihan shalat khusyuk.

\section{Tahap Pelaksanaan Intervensi}

a. Memberikan skala kepada subjek penelitian untuk mengetahui kebahagiaan yang dirasakan oleh subjek penelitian sebelum dan sesudah diberikan perlakuan pelatihan shalat khusyuk b. Mengelompokkan subjek menjadi dua kelompok yang terdiri dari kelompok eksperimen dan kelompok kontrol dengan masingmasing berjumlah 5 orang yang memiliki tingkat kebahagiaan yang rendah

c. Melakukan pelaksanaan rancangan penelitian yang telah disusun oleh peneliti. Pelatihan shalat khusyuk terdiri dari 3 kali pertemuan, masing-masing pertemuan terdiri dari 4 dan 5 sesi dengan rentang waktu 100-240 menit. Total waktu pelaksanaan pelatihan shalat khusyuk adalah 490 menit.

d. Dua minggu setelah pelaksanaan pelatihan, akan diadakan tindak lanjut (follow up) untuk mengetahui kondisi subjek penelitian dengan memberikan skala untuk mengukur tingkat kebahagiaan setelah diberikan pelatihan.

\section{Metode Analisis Data}

Metode analisis data yang digunakan dalam penelitian ini adalah uji Mann Whitney. Uji analisis tersebut digunakan untuk membantu peneliti dalam membedakan hasil kinerja kelompok yang terdapat dalam sampel ke dalam 2 kelompok dengan 2 kriteria yang berbeda. Analisis data ini dilakukan menggunakan program Statistical Program for Science (SPSS) for Windows versi 22.0.

\section{HASIL PENELITIAN}

Hipotesis yang diajukan dalam penelitian ini adalah adanya pengaruh pelatihan shalat khusyuk terhadap peningkatan kebahagiaan pada caregiver pasien stroke. Kelompok yang diberikan perlakuan memiliki tingkat kebahagiaan yang lebih tinggi dibandingkan dengan kelompok yang tidak diberikan perlakuan. Uji hipotesis dalam penelitian ini 
menggunakan uji Mann Whitney. Distribusi data dikatakan hipotesis diterima apabila $\mathrm{p}$
$<0,05$, sedangkan apabila $\mathrm{p}>0,05$ maka

hipotesis ditolak.

Tabel 1. Uji hipotesis menggunakan uji Mann Whitney

\begin{tabular}{cccc}
\hline Variabel & Pengukuran & $\mathbf{Z}$ & $\mathbf{P}$ \\
\hline \multirow{2}{*}{ Kebahagiaan } & Prates & $-1,888$ & 0,059 \\
\cline { 2 - 4 } & Pascates & $-2,323$ & 0,020 \\
\cline { 2 - 4 } & Tindak Lanjut & $-2,323$ & 0,020 \\
\hline
\end{tabular}

Berdasarkan tabel 1 di atas, pada pengukuran paskates diperoleh hasil uji hipotesis yaitu $\mathrm{Z}=-2,323$ dengan $\mathrm{p}=0,020$ $(\mathrm{p}<0,05)$. Hal tersebut menunjukkan bahwa terdapat peningkatan skor kebahagiaan yang signifikan pada kelompok eksperimen yaitu caregiver pasien stroke setelah diberikan pelatihan shalat khusyuk, dibandingkan dengan kelompok kontrol yang tidak diberikan perlakuan. Selain itu, adanya peningkatan skor kebahagiaan pada kelompok eksperimen dibandingkan kelompok kontrol juga terlihat pada pengukuran tindak lanjut yang dilakukan dua minggu setelah diberikan pelatihan shalat khusyuk dengan hasil $\mathrm{Z}=-2,323$ dan $\mathrm{p}$ $=0,020(\mathrm{p}<0,05)$.

\section{PEMBAHASAN}

Penelitian ini bertujuan untuk mengetahui peningkatan kebahagiaan pada caregiver pasien stroke yang diberikan pelatihan shalat khusyuk. Berdasarkan analisis data dan hasil penelitian yang telah dilakukan, ditemukan adanya perbedaan tingkat skor kebahagiaan antara kelompok eksperimen yang diberikan perlakuan berupa pelatihan shalat khusyuk dengan kelompok kontrol yang tidak diberikan pelatihan shalat khusyuk. Kelompok eksperimen yang diberikan perlakuan memiliki skor kebahagiaan yang lebih tinggi dibandingkan dengan kelompok kontrol yang tidak diberikan perlakuan. Perbedaan tingkat kebahagiaan kedua kelompok juga dapat dilihat dari hasil tabel rerata ataupun grafik dan hasil data secara kualitatif yang menjelaskan mengenai kondisi subjek setelah mendapatkan pelatihan shalat khusyuk. Adapun perubahan skor kebahagiaan pada kelompok eksperimen dari sebelum diberikan perlakuan, berada pada kategori sedang. Kemudian setelah diberikan perlakuan dan juga pada saat tindak lanjut, terlihat adanya peningkatan skor kebahagiaan yaitu pada kategori tinggi.

Peningkatan skor kebahagiaan pada caregiver dalam penelitian ini tidak lepas dari pengaruh edukasi dan pelatihan shalat khusyuk. Para caregiver mengungkapkan adanya perubahan positif dalam dirinya setelah diberikan pelatihan shalat khusyuk. Para caregiver merasa menjadi lebih tenang dan mulai bisa mengontrol emosinya agar tidak mudah marah ketika berhadapan langsung dengan pasien stroke. Selain itu, shalat juga menyebabkan kebahagiaan dan kegembiraan dalam pikiran, mengurangi kecemasan, dan memadamkan api kemarahan. Kebahagiaan itu sendiri dapat dilihat dari emosi positif individu akan kepuasan masa lalu, optimis akan masa depan, dan merasa bahagia di masa kini (Seligman, 2005).

Selain itu, para subjek dapat berpikir lebih positif seperti mencoba untuk lebih sabar dan ikhlas dalam menjalankan perannya sebagai seorang caregiver bagi anggota keluarganya yang menderita stroke. Bahkan para caregiver juga merasa bahwa setelah berkali-kali mempraktekkan shalat khusyuk, mereka menjadikan kondisi 
kehidupannya saat ini sebagai cobaan yang harus dilalui untuk mendapatkan ridho Allah SWT. Hal tersebut didukung dengan surat Al-Baqarah ayat 45-46 yang artinya adalah:

"Jadikanlah sabar dan shalat sebagai penolongmu. Dan sesungguhnya yang demikian itu sungguh berat kecuali bagi orang-orang yang khusyuk, (yaitu) orang-orang yang meyakini bahwa mereka akan menemui Tuhannya dan bahwa mereka akan kembali kepada-Nya".

Ayat tersebut menjadi salah satu dasar dalam memberian pemahaman kepada subjek mengenai shalat khusyuk yang disampaikan terapis dalam pertemuan pertama pelatihan shalat khusyuk.

Ayat di atas menghimbau bahwa individu hendaknya meminta tolong hanya kepada Allah SWT, yaitu pertama dengan sabar, tabah, dan teguh, sehingga tidak terguncang hatinya ketika mengalami kesulitan. Sabar dapat dijadikan sebuah benteng. Kemudian, yang kedua adalah shalat, yaitu agar jiwa selalu dekat dan lekat kepada Allah SWT. Individu yang seimbang antara sabar dan shalatnya, maka hatinya akan jernih dan jiwanya juga besar dalam menghadapi rintangan ataupun kesulitan di hidupnya. Dibutuhkan jiwa yang kuat dan pendirian yang kokoh dalam menghadapi kesulitan, sehingga individu selalu meminta pertolongan dari Allah SWT, agar dikuatkan dalam menghadapi kesulitan. Sabar dan shalat menjadikan hati menjadi tabah dan selalu mendekatkan diri kepada Allah SWT. Selain itu, terkadang hati terasa berat dalam menghadapi kesulitan, sehingga diperlukan shalat khusyuk sekurang-kurangnya 5 waktu sehari semalam agar hati menjadi kuat kembali. Khusyuk itu sendiri artinya tunduk, rendah hati dan insaf bahwa Allah SWT cinta kepada hamba-Nya dan percaya bahwa nikmat yang Allah SWT berikan lebih besar dibandingkan cobaan yang Allah SWT berikan. Untuk meningkatkan khusyuk hendaknya individu selalu ingat bahwa seakan-akan itu adalah shalatnya yang terakhir. Meyakini bahwa segala yang datang ke dunia atas kehendak Allah SWT dan akan kembali ke akhirat juga atas kehendak Allah SWT, sehingga akan semakin khusyuk hatinya dalam menghadap Allah SWT.

Begitu juga yang dialami oleh subjek yang telah menjadikan sabar dan shalat sebagai sumber pertolongan dalam menghadapi permasalahannya. Ketika subjek merasa kondisinya dalam merawat pasien stroke terasa berat, maka subjek dapat mengatasinya dengan bersabar dan menjalani ibadah shalat secara khusyuk. Selain itu, subjek mengharapkan bahwa Allah SWT akan menguatkan hati dan jiwanya dalam menghadapi kesulitan dalam hidupnya. Demikian itu yang disebut sebagai sebuah pertolongan dari Allah SWT setelah hamba-Nya bersabar dan menjalankan shalat dengan khusyuk.

Manfaat dari shalat dengan khusyuk adalah mendekatkan diri kepada Allah SWT, menjauhkan penyakit dari tubuh, membuat jiwa dan raga aktif, mendapatkan asupan gizi bagi ruh dan hati, meredamkan nafsu syahwat, menerangi hati, melapangkan dada, dan membuat jiwa bahagia (Ahmad, 2008). Pada saat individu melaksanakan shalat secara khusyuk, kemudian hati telah tersambung kepada Allah SWT maka akan mengantarkan menuju ketenangan jiwa dan pikiran (Purwanto, 2014). Ketenangan dimunculkan pada saat melaksanakan shalat, terutama pada saat gerakan sujud karena individu berada pada gelombang alfa paling tinggi dibandingkan gerakan shalat lainnya. Hal tersebut dikarenakan adanya peningkatan fokus individu pada satu titik pusat dan adanya fokus pada kepala yang menyentuh titik terendah yaitu tanah. Sesuai dengan pernyataan subjek bahwa ketika sujud, subjek memberikan waktu lebih lama sembari berdoa dalam hati karena berasa dalam kondisi yang tenang. 
Tidak hanya pada saat melaksanakan shalat khusyuk saja subjek menjadi lebih tenang. Pada sesi sharing, para subjek juga mengaku sedikit lebih lega karena telah mengungkapkan perasaan yang selama ini dirasakan. Para subjek merasa tidak memiliki teman untuk bercerita terkait masalah yang dihadapi sehingga terkadang merasa jenuh, kesepian ataupun stres. Hal tersebut juga disebutkan dalam penelitian sebelumnya yang dilakukan oleh Daulay et al., (2014) bahwa caregiver seringkali mengalami stres yang disebabkan oleh beratnya tugas yang harus dilakukan dalam merawat pasien stroke. Masalah yang ditimbulkan dari peran keluarga sebagai caregiver akan mengakibatkan caregiver tidak dapat memenuhi fungsinya secara optimum, berdampak pada penurunan kebahagiaan mereka.

Salah satu faktor yang mempengaruhi kebahagiaan individu adalah terkait kehidupan sosial, di mana setiap individu yang bahagia menghabiskan waktu di dalam hidupnya dengan bersosialisasi dengan orang lain. Hal tersebut sesuai dengan pernyataan Seligman (2005) bahwa individu yang sangat bahagia menjalani kehidupan sosial yang memuaskan, paling sedikit menghabiskan waktu sendirian dan mayoritas dari mereka bersosialisasi. Berbeda halnya dengan kondisi caregiver pasien stroke yang menghabiskan waktu dengan merawat anggota keluarganya yang menderita stroke dan menjadi kurang memiliki waktu untuk bersosialisasi dengan lingkungan sekitar karena harus berada di rumah mendampingi pasien stroke.

Selanjutnya, pada saat praktek wudhu dan shalat para subjek merasa teringat akan kesalahan-kesalahan di masa lalu. Para subjek merasa malu kepada Allah SWT ketika meminta ampunan karena merasa dirinya penuh dengan dosa dan takut akan balasan dari kesalahannya serta takut apabila ibadah shalatnya selama ini tidak diterima. Munculnya perasaan takut pada diri para subjek, menunjukkan adanya al-Haibah yang artinya merasa takjub terhadap keagungan Allah dan takut akan siksaan Allah. Di mana para subjek merasa dirinya makhluk yang lebih kecil dihadapan Allah, serta mengakui bahwa Allah Maha Besar.

Munculnya perasaan malu pada diri para subjek, menunjukkan adanya al-Haya' yang artinya merasa malu kepada Allah atas segala kekurangan dan ketidaksempurnaan dalam beribadah. Hal tersebut menunjukkan bahwa para subjek menyadari atas kesalahan-kesalahan yang telah diperbuat di masa lalu. Meskipun demikian, para subjek tetap berharap mendapatkan ampunan dari Allah SWT atas kesalahannya dan berharap dapat menjalankan perintah-Nya dan menjauhi larangan-Nya. Munculnya harapan dalam diri para subjek juga menunjukkan adanya al-Raja' yang artinya selalu menaruh harapan besar kepada Allah agar ibadahnya diterima dan diberikan pahala oleh Allah SWT. Pengharapan di sini diimbangi dengan perasaan takut akan siksaan-Nya, sehingga individu akan beribadah dengan lebih baik lagi dalam menjalankan perintah-Nya.

Faktor lain yang mempengaruhi kebahagiaan seseorang adalah religiusitas. Individu yang religius lebih bahagia dan lebih puas terhadap kehidupan daripada individu yang tidak religius (Seligman, 2005). Pada kondisi para subjek yang masih merasakan adanya kesedihan dan kemarahan di dalam dirinya, dikarenakan kurangnya menghadirkan Allah SWT dalam merawat anggota keluarganya yang menderita stroke, cenderung kurang puas dan kurang ikhlas dalam menerima kondisi hidupnya. Hal tersebut sesuai dengan penelitian sebelumnya yang dilakukan oleh Ros Mayasari (2014) bahwa religiusitas berkontribusi secara langsung ataupun tidak langsung terhadap kebahagiaan individu melalui pemberian makna dan tujuan hidup manusia. 
Selama 2 minggu setelah mengikuti pelatihan dan terus mencoba mempraktekkan shalat khusyuk dalam shalat 5 waktu maupun shalat sunnah, para subjek menjadi ingin terus mendekatkan diri kepada Allah SWT dan juga adanya perasaan bersyukur karena masih adanya bantuan dari orang lain dalam merawat anggota keluarganya yang menderita stroke. Para subjek juga merasa tenang, tentram, dan bahagia dalam menjalani kehidupan seharihari. Hal tersebut sesuai dengan pernyataan (Purwanto, 2014) bahwa ketika melaksanakan shalat dan hati tersambung kepada Allah, maka akan mengantarkan kepada ketenangan jiwa dan pikiran.

\section{SIMPULAN DAN SARAN}

Berdasarkan hasil dari penelitian yang telah dilakukan menunjukkan bahwa terdapat peningkatan yang signifikan skor kebahagiaan antara caregiver pasien stroke pada kelompok eksperimen setelah diberikan perlakuan berupa pelatihan shalat khusyuk, dibandingkan dengan caregiver pasien stroke pada kelompok kontrol. Kelompok yang mendapatkan pelatihan shalat khusyuk memiliki tingkat kebahagiaan yang lebih tinggi dibandingkan dengan kelompok yang tidak mendapatkan pelatihan shalat khusyuk. Hal tersebut menunjukkan bahwa shalat secara khusyuk terbukti memberikan perasaan tenang dan bahagia bagi seseorang yang melaksanakannya dengan memahami setiap bacaan shalat dan memperbaiki gerakan shalat. Ketika perasaan caregiver pasien stroke tenang dan bahagia, maka para caregiver akan menjadi lebih ikhlas dalam menjalankan perannya sebagai seorang caregiver bagi anggota keluarganya yang menderita stroke dan tidak lagi menganggap anggota keluarganya yang menderita stroke sebagai beban hidupnya. Ketenangan tersebut muncul karena para caregiver percaya bahwa Allah SWT yang akan memberikan pertolongan kepadanya.

\section{Saran}

Hasil penelitian ini dapat menjadi tambahan referensi bagi penelitian selanjutnya, mengingat masih belum banyak penelitian yang menggunakan pendekatan religius pada caregiver pasien stroke. Selain itu, peneliti selanjutnya dapat menambahkan jumlah subjek karena dapat mempengaruhi hasil dari efektivitas penelitian ini. Selain itu, peneliti harus memperhatikan kondisi para subjek yang harus meninggalkan pasien stroke dalam beberapa waktu untuk mengikuti pelatihan shalat khusyuk, sehingga diharapkan peneliti selanjutnya dapat mempersingkat waktu pelaksanaan pelatihan shalat khusyuk.

Subjek dalam penelitian ini diharapkan untuk terus mempraktekkan yang sudah didapatkan dalam pelatihan shalat khusyuk untuk lebih meningkatkan kebahagiaan. Ketika terus mencoba melakukan shalat dengan khusyuk, harapannya para subjek dapat lebih tenang dan ikhlas dalam menjalankan perannya sebagai seorang caregiver bagi anggota keluarganya yang menderita stroke. Bagi Puskesmas Mlati 2, diharapkan mengadakan program pendampingan kepada para caregiver. Hal tersebut dapat meningkatkan kualitas hidup mereka. 


\section{DAFT AR PUST AKA}

Agusthia, M. (2018). Pengaruh terapi psikoedukasi terhadap beban caregiver dalam merawat penderita stroke. Jurnal Endurance, 3(2), 278283.

https://doi.org/10.22216/jen.v3i2.27 41

Ahmad, B. S. (2008). Misteri pengobatan dalam shalat; Menguap rahasia pengobatan dan kesehatan dalam ibadah shalat. Mirqad Media Grafika.

Al-Ghazali, A. H. (2011). Ihya' Ulumuddin (M. A. Rathony (ed.)). Al-Makhtabah Attijjariyah Al-Kubro.

Ayuningputri, N., \& Maulana, H. (2014). Persepsi akan tekanan terhadap kesejahteraan psikologis pada pasangan suami-istri dengan stroke. Jurnal Psikologi Integratif, 2(2), 27-34. https://doi.org/10.14421/jpsi.2014.\% $\mathrm{x}$

Cameron, J., Naglie, G., Gignac, M. A. M., Bayley, M., Warner, G., Green, T., Czerwonka, A., Huijbregts, M., Silver, F. L., Phillips, S. J., \& Cheung, A. M. (2014). Randomized clinical trial of the timing it right stroke family support program: Research protocol. BMC Health Services Research, 14(1), 18. https://doi.org/10.1186/1472-696314-18

Daulay, N. M., Setiawan, \& S, N. F. (1970). Pengalaman Keluarga sebagai Caregiver dalam Merawat Pasien Strok di Rumah. Jurnal Keperawatan Padjadjaran, 2(3), 161-170. https://doi.org/10.24198/jkp.v2i3.86

Departemen Kesehatan, R. (2018). Riset kesehatan dasar 2018. Badan Penelitian dan Pengembangan Kesehatan Kementrian Kesehatan RI.

Fahrunnisa, \& Solichach, M. (2017). Strategi coping pada caregiver penderita stroke. Jurnal Psikologi Integratif, 5(1),
$1-10$.

https://doi.org/10.14421/jpsi.2017.\% $\mathrm{x}$

Fajriyati, Y. N., \& Asyanti, S. (2017). Coping stres pada caregiver pasien stroke. Indigenous: Jurnal Ilmiah Psikologi, 2(1), 96-105. https://doi.org/10.23917/indigenous. v2i1.5460

Hanum, P., Lubis, R., \& Rasmaliah. (2018). Hubungan karakteristik dan dukungan keluarga lansia dengan kejadian stroke pada lansia hipertensi di Rumah Sakit Umum Pusat Haji Adam Malik Medan. JUMANTIK, 3(1), 44-64.

https://doi.org/10.30829/jumantik.v3 i1.1377

Icekson, T., Roskes, M., \& Moran, S. (2014). Effects of optimism on creativity under approach and avoidance motivation. Frontiers in Human Neuroscience, 8(105), 1-6.

https://www.frontiersin.org/article/1 0.3389/fnhum.2014.00105

Ifadah, N. (2015). Peningkatan kebahagiaan melalui pelatihan kekuatan diri (strength centered) berbasis syukur pada wanita muslim yang berperan ganda (dual career) di Yogyakarta [Skripsi, UIN Sunan Kalijaga]. Digilib UIN Sunan Kalijaga. http://digilib.uinsuka.ac.id/19424/

Mayasari, R. (2014). Religiusitas islam dan kebahagiaan (sebuah telaah dengan perspektif psikologi). Al-Munzir, 7(2), 81-100.

National Alliance for Caregiving. (2015). Caregiving for the family caregiver. The AARP Public Policy Institute.

Nurtalatthaf, H. (2017). Pelatihan shalat khusyuk untuk meningkatkan kebermaknaan hidup pada penyandang disabilitas fisik [Magister tesis, Universitas Islam Indonesia]. 
Universitas Islam Indonesia.

Okta, I. W., \& Santi, M. (2015). Hubungan antara karakteristik pasien stroke dan dukungan keluarga dengan kepatuhan menjalani rehabilitasi. Jurnal Berkala Epidemiologi, 3(1), 24-34. http://repository.unair.ac.id/id/eprint $/ 64234$

Pontoh, Z., \& Farid, M. (2015). Hubungan antara religiusitas dan dukungan sosial dengan kebahagiaan pelaku konversi agama. Persona:Jurnal Psikologi Indonesia, 4(1), 100-110. https://doi.org/10.30996/persona.v4i 1.495

Purwanto, S. (2014). Catatan harian trainer shalat khusyuk. Solo Romiz Aisy. https://onesearch.id/Record/IOS3107 .UMS:56893\#description

Rahardjo, W. (2007). Kebahagiaan sebagai proses pembelajaran. Jurnal Penelitian Psikologi, 2(12).

Sangkan, Abu. (2004). Pelatihan shalat khusyu (1st ed.). Jakarta Yayasan Shalat Khusyuk dan Manajemen Masjid Baitul Ikhsan Bank Indonesia. http://103.255.15.77/detailopac?id=259027

Sari, A. D. K., \& Subandi. (2015). Pelatihan teknik relaksasi untuk menurunkan kecemasan pada primary caregiver penderita kanker payudara. Gadjah Mada Journal Of Professional Psychology, 1(3), 173-192. https://doi.org/10.22146/gamajpp.93
93

Seligman, M. E. P. (2005). Authentic happines: Menciptakan kebahagiaan dengan psikologi positif. Mizan Pustaka.

Suparman, D. (2015). Pembelajaran ibadah shalat dalam perpektif psikis dan medis. Jurnal ISTEK, 9(2), 1979-8911. https://journal.uinsgd.ac.id/index.php /istek/article/view/188

Wardani, Y., Nashori, F., \& Uyun, Q. (2016). Efektivitas pelatihan shalat khusyuk dalam menurunkan kecemasan pada lansia hipertensi. Jurnal Intervensi Psikologi (JIP), 8(2), 217-233. https://doi.org/10.20885/intervensip sikologi.vol8.iss2.art5

World Health Organization [WHO]. (2014). Stroke, cerebrovascular accident. https://www.who.int/healthtopics/cardiovasculardiseases/\#tab=tab_1

Yayasan Stroke Indonesia [YASTROKI]. (2012). Indonesia tempati urutan pertama di dunia dalam jumlah terbanyak pasien stroke. Yayasan Stroke Indonesia (YASTROKI). http://www.yastroki.or.id/read.php?i $\mathrm{d}=341$ 